\title{
Efficiency of social investment projects from the position of the institutional approach
}

\author{
Valerya Glazkova ${ }^{1, *}$, Elizaveta Marchenko ${ }^{2}$ \\ ${ }^{1}$ Moscow State University of Civil Engineering, 129337, 26, Yaroslavskoye Shosse, Moscow, Russia \\ ${ }^{2}$ Vladimir State University named after Alexander and Nikolay Stoletovs, 600005, Vladimir Region, \\ Vladimir, Gorkogo str, 79, Russian
}

\begin{abstract}
The research objective is the development of the recommendations for the assessment of the efficiency of social investment projects, which fixes the uniform approach to the assessment, taking into account the interests of all the interested parties. The creation of effective institutes in the market economy of our country is one of pressing issues now. The efficiency of investments into social investment projects is considered in terms of the theory of institutionalism. It is offered to consider the assessment of the efficiency of social projects which is based on the methodical norms and rules that allow carrying out the assessment uniformly, on the basis of the uniform reasonable principles, with equal accounting of interests of all the interested parties. The social investment project is the form of manifestation of such an institute. Society, state, business, and future generations are considered as the economic agents of the assessment of efficiency. The institutional approach to the assessment of efficiency of the implementation of social investment projects that allow estimating the behavior of agents and operating the system of their relations is the result of the research. The result of the research can be applicable for the assessment of efficiency of the social investment project by any of the agents considered within the offered institute.
\end{abstract}

\section{Introduction}

Despite difficult economic conditions in the Russian Federation, the growth and maintenance of a worthy level of living of the population remain the main task of the country development. The need to comply with the principles of the sustainable development determines the need of social investments.

The implementation of social investment projects has to take place according to the innovative strategy of the state. Today many economists (Tkachyov A.G., Popov A.I., Kossov V.V., Ivanilov E.B., Sukharev O., etc.) recognize the important role of the state during the determining and realization of technological, social-and-economic and macroeconomic transformations. The state has to mobilize the society by the means of the common orientation and also to create the conditions, promoting innovative investment process in the country [1].

\footnotetext{
*Corresponding author: leram86@mail.ru angela-1309.m@yandex.ru
} 
As a rule, socially directed state regulation of the economy is based on the balance of "social" and "market" interests, to keep public administration in the main strategic directions and macroeconomic processes. At the same time, the combination of the state regulation and the development of an economic initiative, economic independence becomes the basic principle of the social state.

It was in the end of the 19th century, when A. Wagner proved the law of "strengthening of the state activity" and the related law of "the increasing expansion of financial requirements of the state and the growth of public expenses" in which he noted the trend of transition from "the state of order" to "the state of welfare", having defined the increasing role of the state in carrying out the imperious and legal purposes, purposes of the development of culture and people's welfare [2].

Research by R. Barro, D. Ashauer, T. Persson's and others prove the positive influence of the public expenditures, directed education, health care and defense to their economic growth.

In this regard, institutional approach to the economy is interesting. Its representatives (T. Veblen, U. Mitchell, J. Hodgson, J. Galbraith, etc.) considered the driving force of the economy along with material factors and spiritual, moral, legal and other non-economic factors [3, 4]. Works by the American scientists J. Kommons and U. Mitchelk1, and also their successors, are joined by the idea of taking into account the economic growth of all the public relations and the need of the state intervention in the economy [5]. French economist F. Peru and other representatives of the concept of dirigism proved the need of active intervention of the state in the economic governance, in particular, by the means of indicative planning.

In turn, representatives of neoinstitutionalism R. Coase, D. Nort and J. Buchanan proved the high importance of the state as a regulator and as a supplier of the public benefits [6].

According to J.Yu. Stiglitz, there are six reasons explaining why the market mechanism cannot lead to the effective distribution of resources and why the public administration is necessary: they are insolvency of the competition, public goods, outer effects, incomplete markets, imperfection of information and unemployment. That is the state has to manage actively where in the market the monopoly dominates and there is no strong competition, or there are obstacles for entry into the industry (that means the insolvency of the competition according to J. Stiglitz). State regulation is also necessary for the delivery of public goods or services (for example, national defense) which either cannot be put by the market, or can be put in a small amount. Information can be the public good too, and imperfection of the process of its granting by the market (the phenomenon called by J. Stiglitz "the incomplete market", that is the market which is not able to provide any goods or service) results in the need of the state intervention and regulation of distribution of this resource. Besides, the state is capable to react to the outer effects, making impact on the market more effectively, than business and also to regulate the employment, when the market is not able to provide full employment [7].

Within the neoinstitutional theory, the approach proceeding from two following prerequisites on the need of social institutes (according to Nort's interpretation, the rules regulating economic behavior), and on the possibilities of their analysis by the means of the concepts and methods developed by economic science, is formed. Still T. Veblen and U. Mitchell were sure that there is no full coincidence of private and public interests, therefore, the state intervention in the economy is necessary, and one of the most important issues of the economic science is to develop particular methods of such intervention. Such ideas are supported by modern economists Rosenthal V.O., Ponomareva O.S., Greenberg R., Vasilyev V.L., Shiryaeva R.I., etc., who speak about the need of creation of the relevant institutes, allowing to organize the economic development forecasting, anti-recessionary 
regulation, to adjust the mechanism of monetary circulation, to regulate employment, etc. [8-9].

So R. Greenberg writes that chances of the movement of the country to the civil society and social market economy remain. The concept of the economic sociodynamics (CES) offered by Greenberg together with professor A.Ya. Rubenstein and supposing that "the social usefulness" of the benefit serves as the key category proves the objective need for the systematic public financing of culture, science, health care, education and "gives the practical basis for the activity of the state, connected, in particular, with financing of the social sphere".

\section{Methods, Information basis and State-of-the-Art}

The following methods were used in the research: methods of mathematical statistics and modeling, method of expert evaluations, logical and economic method of the research, separate elements of system approach.

Laws and regulations on the estimates of the efficiency of investment projects, publications of domestic and foreign authors, abstracts and other information, data of Goskomstat of Russia made up the information basis of the research.

Nowadays, it is difficult to overestimate the role of institutes in the modern economic life. As Romanovsky D.S. considers, the interaction between people is ordered, and the conflicts arising in the world of limited resources, are resolved thanks to the institutes. Romanovsky cites the developed definition of institute, given by the Nobel Prize laureate Eleanor Ostrom. She understands the institutes as the "set of the existing rules on the basis of which it is established who has the right to make decisions in the respective areas, what actions are allowed in the respective areas, what general rules will be used, what procedures need to be followed, what information has to be defined and what prize will be received by the individuals depending on their actions ... All the rules contain instructions, which forbid, resolve or demand certain actions or decisions. The existing rules are such rules, which are really used, which compliance is monitored, and they are protected by the corresponding mechanisms, when individuals choose those actions which they intend to undertake..." [10].

Nowadays, the creation of effective institutes in the market economy of our country is one of the pressing tasks. The necessary prerequisite and the condition for the creation and effective functioning of the market economy in the Russian Federation is the formation of a certain set of the relevant institutes. The set of institutes and the institutional relations form the institutional basis of the economic system of the society.

The institutional structure of the society is understood as a certain set of the institutes, creating the matrixes of economic behavior, defining restrictions for the economic entities, which are formed within some systems of coordination of the economic activity.

To reveal the essence of economic institute and to define mechanisms by means of which the institutes get and realize the economic value, it is necessary to understand the functions, which institutes perform in the economic life as well as in the activity of economic agents (fig. 1.).

The destruction of the fundamentals of the command economy did not become the sufficient condition for the formation of the viable market relations and did not lead to the growth of welfare of overwhelming quantity of citizens of our country. Some economists connect this phenomenon with the impossibility within the economic activity to be guided only by the principles of maximizing profit; it is necessary to take the factors, defining the activity of the person into consideration. In such conditions, the role of the state which forms "rules of the game" and acts as a full participant of the economic relations changes 
too. In this regard, there is a need of creation of the institutional mechanism of the growth in the prosperity of citizens.

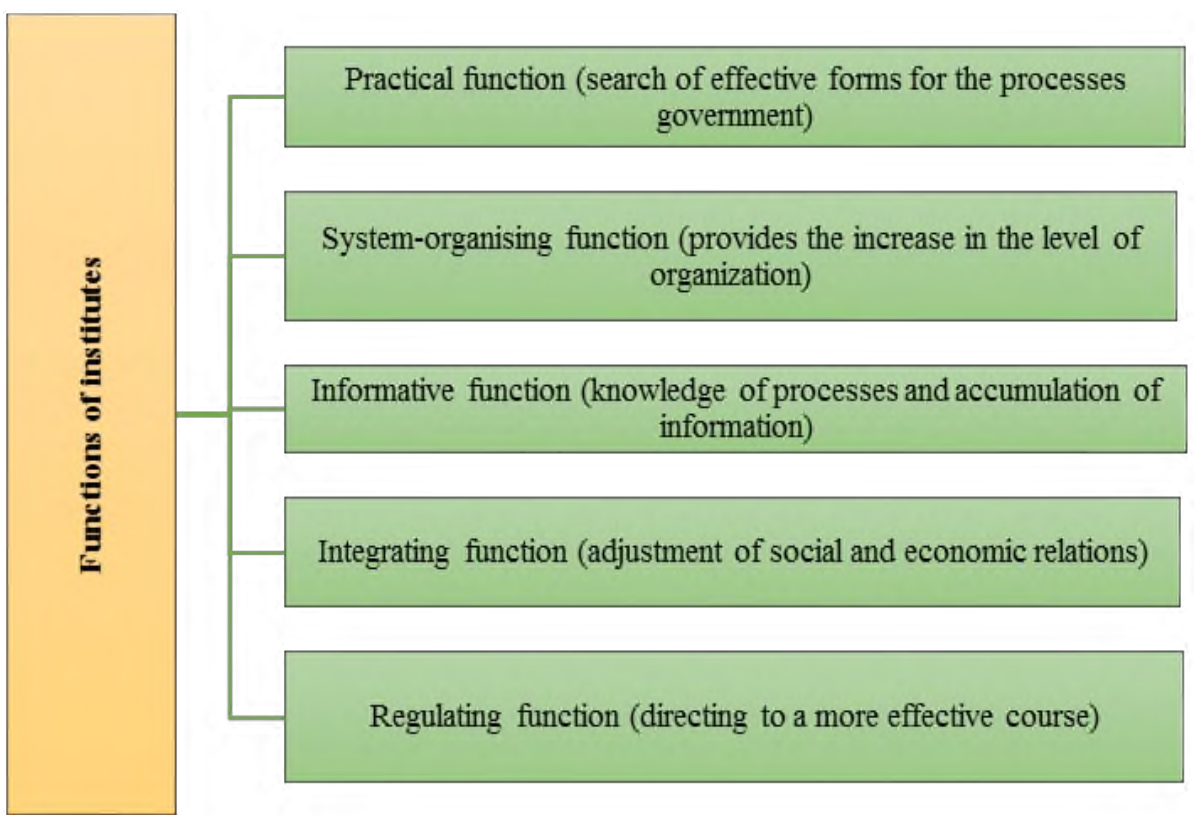

Fig. 1. Functions of institutes in the economy

During the period since the end of the 1990 to the beginning of the 2000, Russia passed the way of initial formation of new institutional structure of the economy. However, many Russian economists (Radygin A.D., Entov R.M., Abramov A.E., Mezheraups I.V., Malginov G.N., Sizov A.V., Shmelyova N.A. and others) come to the conclusion that now it is still early to speak about the achievement of a relative maturity of institutes in Russia. At the same time, in their opinion, the first stage of the institutional development and the formation of the sphere of formal institutes is complete, and the key long-term tasks can ensure the stability of the developed institutional environment and adaptability of the created institutes. In fact, it is about the "exact control" according to the changing economic realities.

The efficiency of institutes determines the level of expenses on business, appeal of participation in business for private investors, investment activity in the country, the level and quality of the competition in the markets and therefore it influence the rates of the economic growth in the country.

The inefficiency of the state institutes of our country is connected, first of all, with the abundance of natural resources, namely oil resources: it is possible to argue that the existence of easy additional sources of income allow postponing the solution of the most important fundamental problems of the development of the society including institutes. The inefficient state system is not able to use the oil revenues effectively; that is the obstacle for the transition to the innovative type of the economic growth.

Together with that fact, there is one more problem, "rich agents", who have the sufficient volume of the political power, can abuse certain institutes for extraction of their own benefit; that is the nonintegral use of institutes. And if such phenomenon increases in wide scales, the ability of institute to perform their function is lost, and in this case the institute does not make the expected contribution to the economic development. 


\section{Results}

The authors believe that the prospects of the sustainable development of the country, the growth in the well-being of the Russian citizens, the homeland security, the dynamic development of the economy are determined by the efficiency of the implementation of social investment projects in many respects.

The implementation of such projects has to be fixed by the relevant institute for the regulation of behavior of the economic agents during the implementation of social investment projects as well as for the decrease in uncertainty of the environment

The assessment of the social projects' efficiency, which is based on the methodical norms and rules (the environment of institute), allowing us to carry out the assessment uniformly on the basis of the uniform reasonable principles, with equal extent of accounting of interests of all interested agents (fig. 2) [11-12] can become such an institute.

The considered institute of the assessment of the social investment projects efficiency is the economic institute, having recommendatory, but not directive character. The assessment of the social project efficiency can be considered to be a formal institute, as it is based on the principles and rules of the assessment and it has to be fixed legislatively [13].

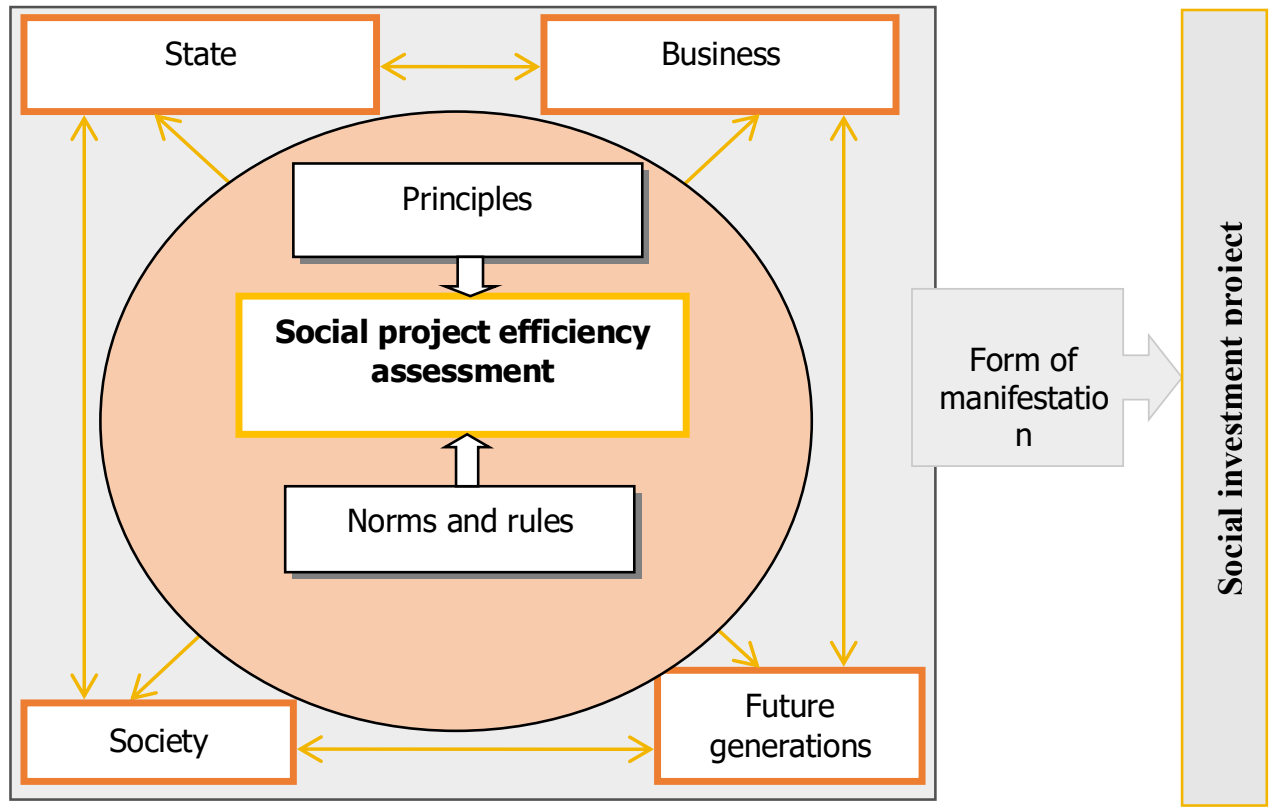

Fig. 2. Institutional approach to the assessment of the social investment project

Social investment project, which is approved to implementation on the basis of criteria and parameters of the assessment of its efficiency, put in the technique is the form of the manifestation of the institute considered in the Figure 2.

In turn, the approved project represents the contract signed between the economic agents for fixing relationship, resulting from the implementation of the social investment projects in a legal form. As E.G. Furubotn and R. Richter write, "the institutional economic theory deals with a system which limits possible behavior of individuals by means of sanctions. Source of sanctions: either law, or custom" [14].

As the formation of institutes is an endogenous process based on the already existing experience of interaction of people and their history, the institutes reduce the choice costs in the conditions of uncertainty of the environment and allow structuring the costs of its functioning [15]. 
The persons interested in this institute act as economic agents of the institute of the assessment of the social investment projects efficiency: society, state, business, and future generations, having their interests and the purposes. During implementation of a social investment projects, stable relations among economic agents are formed. These communications, in turn, lead to the emergence of steady structures of the relations. i.e. networks. Such network among the state, society, business and future generations is shown during the development and implementation of the social project, for example, in the form of the development of the corporate social responsibility and public-and-private partnership, creation of public councils and other forms of cooperation of the state and business [16-17].

The implementation of social projects will lead to the improvement of quality and level of living for the population. The implementation of social projects will lead to the creation of completely existing, steadily developing public system having steadily functioning, dynamically developing economy and social policy for the state. The implementation of social projects will lead to the increase in labour productivity and creation of favorable image of the company for business. Nowadays, the implementation of social projects means protection of welfare, requirements and interests of future generations [18].

The behavior of society within the considered institute is determined from the outside, therefore we speak about society as about an economic agent.

Future generations are also considered as an economic agent, as they depend on the results of the projects implementation, but nominally do not exist and cannot physically make any decisions [19-20].

At the same time, the positions of such economic agents as the state and business are considered from the position of the actor, that is a person, who are consciously acts and makes some significant decisions for himself or herself and for others.

Any project (from creation something new before to the simple change of something already existing) is the result of choice and search of several alternative options by the person, making the decision (decision-maker). Moreover, if the existing options do not suit the decision-maker as a result of search, he or she begins to look for new options; that is why it is necessary to speak about the decision-maker as about an active agent, an actor [21-22]. During implementation of social investment projects by the state, the decisionmaker is presented by the group of experts from various state structures, which are responsible for the decision on the project, made by them. During implementation of social investment projects by business, the decision-maker is presented by the group of experts at the level of corporations and companies.

At the same time, it is impossible to forget about great interest of all the economic agents in the successful functioning of the considered institute (states, business, society and future generations). Public can influence the decision-making course on the implementation of the social investment project by the means of public councils (for example) [23].

\section{Conclusion}

According to the representatives of the neoinstitutional theory, real economic agents differ from the model agents, which were built by neoclassics, as the real agents can act with the limited degree of rationality. Often agents care for the realization of own interests and the purposes, not always considering the possible conflict between personal and others' interests [19]. In this regard, it is necessary to estimate the behavior of agents and to operate the system of their relations that it is possible to make within institutional approach to the assessment of the efficiency of the implementation of social investment projects.

Institutional approach is based on the increase of the role of the state in management through the system of the institutes conforming to modern requirements of the development 
of the economy. It is possible to carry out the assessment of the efficiency of social investment projects, which fixes the uniform approach to the assessment of the efficiency of such projects taking into account the interests of all the interested parties to such institutes. The social investment project is the form of the institute appearance. Society, the state, business, and future generations act as economic agents for the assessment of the efficiency.

\section{References}

1. O. Sukharev, Investments in Russia, 1, 3-10, (2017)

2. K. Marx, Remarks on the book by A. Wagner. Textbook of political economy [Digital resource]. - Volume 1 (1879)

3. T. Veblen, Theory of the idle class (Moscow, Librokom, 2011)

4. J. Hodgson, Economic bulletin of the Rostov State University, 6-2, 8-21 (2008)

5. S. A. Abramov, Relevant issues of modern science, 1(4), 3-9 (2015)

6. R. Malikov, K. Grishin, Problems of the theory and practice of business, 2(62) (2017)

7. J. Yu. Stiglitz, Inequality price. What stratification of society threatens our future (Moscow, Eksmo, 2015)

8. V. L. Vasilyev, Innovations, 7, 111-115 (2014)

9. R. I. Shiryaeva, Bulletin of institute of economy of RAS, 3, 110-118 (2014)

10. A. Degtyarev, R. Malikov, K. Grishin, Matters of economy, 11, 83-94 (2014)

11. E. M. Marchenko, V. V. Glazkova, Assessment of efficiency of social innovative and investment projects. Monograph (Vladimir, Transit ICKX, 2015)

12. E. M. Marchenko, V. V. Glazkova, MATEC Web of Conferences, 170, 01049 (2018)

13. V. V. Glazkova, MATEC Web of Conferences, 106, 08096 (2017)

14. E. Furubotn, R. Richter, Institutes and economic theory: Achievements of the new institutional economic theory (St. Petersburg, Publishing house of the St. Petersburg state university, 2005)

15. M. A. Bahauovna, M. A. Bahauovna, International Journal of Applied Engineering Research, 11(9), 6808-6816 (2016)

16. E. Vasilyeva, MATEC Web of Conferences, 170, 01050 (2018)

17. A. Mottaeva, MATEC Web of Conferences, 193, 01022 (2018) https://doi.org/10.1051/matecconf/201819301022

18. Yu. S. Prokhorova, I. V. Karakozova, Economy and entrepreneurship, 6-3(593), 608-613 (2015)

19. V. V. Glazkova, Competitiveness in the global world: economy, science, technologies, 2(1), 40-43 (2017)

20. E. Ganebnykh, A. Mottaeva, T. Larinina, E. Petrova, MATEC Web of Conferences, 170, 01044 (2018) doi.org/10.1051/matecconf/201817001044

21. E. Vasilyeva, Economy and entrepreneurship, 6(83), 607-610 (2017) 
22. E. M. Marchenko, V. V. Glazkova, Bulletin of the Vladimir State University of Alexander Grigoryevich and Nikolay Grigoryevich Stoletovykh. Series: Economic sciences, 2(16), 28-33 (2018)

23. Akhmetshin, E. M., Kovalenko, et al., Journal of Entrepreneurship Education, 21(2) (2018) 